\title{
ARTUR GRUSZCZYŃSKI
}

\section{Przeniesienie wierzytelności z umowy ubezpieczenia majątkowego}

Celem artykułu jest prawna analiza istotnego dla praktyki zagadnienia przenoszenia wierzytelności z umowy ubezpieczenia majątkowego. W tym zakresie autor szczególnq uwagę poświęca analizie treści przepisów art. 823 k.c. oraz 306-310 k.m. dotyczqcych przeniesienia praw z umowy ubezpieczenia w razie zbycia przedmiotu ubezpieczenia, a także wyjaśnieniu stosunku tych przepisów do ogólnej regulacji odnoszącej się do instytucji cesji. W dalszej części rozważań autor podejmuje próbę udzielenia odpowiedzi na pytanie, czy i w jakim zakresie jest dopuszczalne przeniesienie wierzytelności wynikajacej z umowy ubezpieczenia na podmiot, który nie nabył wcześniej przedmiotu ubezpieczenia, a także na taki podmiot, któremu nie przysługuje żaden inny interes majatkowy w stosunku do ubezpieczonego dobra.

Słowa kluczowe: przelew wierzytelności z umowy ubezpieczenia, cesja, zbycie przedmiotu ubezpieczenia, interes ubezpieczeniowy, ochrona ubezpieczeniowa, ubezpieczenie majątkowe.

\section{Wprowadzenie}

Przenoszenie wierzytelności wynikających z czynności prawnych typu zobowiązaniowego odgrywa w praktyce doniosłą rolę dzięki instytucji umowy cesji. Pozwala ona zaspokajać różne, niedające się wyczerpująco wyliczyć, potrzeby uczestników obrotu prawnego ${ }^{1}$. Wyżej wymieniona instytucja wykorzystywana jest powszechnie również w celu przenoszenia wierzytelności powstałych na skutek zawarcia umowy ubezpieczenia. Przykładowo, częstym zjawiskiem jest przelew wierzytelności z tytułu ubezpieczenia na podmiot kredytujący ubezpieczoną rzecz, celem zabezpieczenia kredytu². Zapotrzebowanie na obrót wierzytelnościami z ubezpieczenia istnieje

1. K. Zawada, Przelew wierzytelności, [w:] System prawa prywatnego. Tom VI. Prawo zobowiqzań - część ogólna, [red.] A. Olejniczak, CH Beck, Warszawa 2009, s. 133 ?.

2. J. Pokrzywniak, Komentarz do niektórych przepisów Kodeksu cywilnego, [w:] M. Orlicki, J. Pokrzywniak, Umowa ubezpieczenia. Komentarz do nowelizacji kodeksu cywilnego, Wolters Kluwer, Warszawa 2008, s. 104. 
również w transporcie towarów, szczególnie wtedy gdy ładunek zmienia właściciela przed dotarciem na miejsce przeznaczenia ${ }^{3}$.

Mając na uwadze powszechne wykorzystywanie przenoszenia wierzytelności z umowy ubezpieczenia w praktyce, bez wạtpienia warto dokonać analizy obecnie obowiązujących przepisów prawnych dotyczących tej problematyki. Po nowelizacji Kodeksu cywilnego z 2007 roku $^{4}$ niezwykle ważną regulacja w tym zakresie pozostaje przede wszystkim art. 823 k.c., zgodnie z którym w razie przejścia przedmiotu ubezpieczenia, prawa z umowy ubezpieczenia mogą być przeniesione na nabywcę tego przedmiotu. Ustawodawca przewidział więc, iż do przeniesienia praw z umowy ubezpieczenia może dojść za pomocą odrębnej umowy zawartej pomiędzy zbywcą oraz nabywca przedmiotu objętego ochroną ubezpieczeniową. Co niezwykle istotne, podstawowym warunkiem skuteczności tejże czynności prawnej jest zgoda ubezpieczyciela (chyba że umowa ubezpieczenia lub ogólne warunki ubezpieczenia stanowią inaczej]. Ponadto, doniosłym skutkiem przejścia praw na nabywcę przedmiotu ubezpieczenia jest równoczesne przejście obowiązków, które ciążyły dotąd na zbywcy.

Należy nadmienić, że umowa przenosząca prawa z umowy ubezpieczenia, o której mowa powyżej, została uregulowana w inny sposób niż umowa cesji wierzytelności. Przeniesienie wierzytelności w drodze cesji co do zasady nie wymaga zgody dłużnika, zaś na nabywcę wierzytelności (cesjonariusza) nie przechodzi dług zbywcy (cedenta). Dodatkowo pewnych problemów interpretacyjnych może dostarczać art. 823 § 4 k.c., w którym zastrzeżono, iż przepisów art. 823 § 1-3 nie stosuje się przy przenoszeniu wierzytelności, jakie powstały lub moga powstać wskutek zajścia przewidzianego w umowie wypadku. W związku z powyższym może pojawić się wątpliwość czy umowa przenosząca prawa z umowy ubezpieczenia zawarta na podstawie art. $823 \S 1$ to w rzeczywistości cesja wierzytelności ubezpieczeniowej, czy też zupełnie odrębna instytucja prawna, do której nie mają zastosowania art. 509-518 k.c. Co więcej, z przedmiotową problematyką wiąże się również pytanie o dopuszczalność przeniesienia praw z ubezpieczenia na podmiot, który nie nabył wcześniej samego przedmiotu ubezpieczenia.

Pomimo faktu, iż ubezpieczenia morskie podlegają odrębnemu reżimowi prawnemu niż ubezpieczenia lądowe ${ }^{5}$, przedmiotu niniejszych rozważań nie można zupełnie oderwać od regulacji zawartych w art. 306-310 k.m., które w zasadzie stanowiły wzór dla ustawodawcy przy dokonywaniu zmiany treści art. 823 k.c. w 2007 roku. Należy w tym miejscu jednak wskazać, iż ubezpieczenia morskie również w tym zakresie zachowuja pewne odrębności, w szczególności co do wymogu zgody ubezpieczyciela na zbycie praw, czy też charakteru prawnego polisy ubezpieczeniowej, która na gruncie ubezpieczeń morskich zdaje się posiadać cechy właściwe papierom wartościowym. Problematyka przeniesienia praw w razie zbycia przedmiotu ubezpieczenia nie dotyczy natomiast ubezpieczeń osobowych, w związku z czym w niniejszym artykule nie będa poruszane kwestie związane z tym rodzajem ubezpieczeń.

3. B. Kucharski, Przeniesienie praw z umowy ubezpieczenia, Wolters Kluwer, Warszawa 2010, s. 13.

4. Zmiana została dokonana Ustawą z dnia 13 kwietnia 2007 r. o zmianie Ustawy - Kodeks cywilny oraz o zmianie niektórych innych ustaw (Dz. U. Nr 82, poz. 55?).

5. B. Kucharski, op. cit., s. 15. 


\section{Przedmiot umów przenoszących prawa z ubezpieczenia}

W art. 823 k.c. oraz w art. 306-310 k.m. użyto - jak może się wydawać - dwóch zbliżonych znaczeniowo terminów prawnych tj. praw i wierzytelności z umowy ubezpieczenia. Zdaniem autora niniejszego opracowania dokonanie wyraźnego rozgraniczenia pomiędzy tymi pojęciami może być nie tyle utrudnione, ile w zasadzie niemożliwe, co wynika z przyjętej właściwie jednomyślnie przez przedstawicieli doktryny definicji wierzytelności.

Zgodnie z powszechnym poglądem wierzytelność należy definiować jako prawo podmiotowe przysługujące wierzycielowi, które polega na możliwości żądania od dłużnika spełnienia świadczenia ${ }^{6}$. Wierzytelność określa przy tym złożona sytuację prawną podmiotu, na którą składa się pewien zespół funkcjonalnie powiązanych ze sobą poszczególnych uprawnień, uprawnień kształtujących, roszczeń czy kompetencji. Jak inne prawa podmiotowe, także wierzytelności są wyznaczone przez obowiązujące normy dla ochrony prawnie uznanych interesów podmiotów? Przy tak szerokim pojmowaniu wierzytelności należałoby uznać że jest to pojedyncze prawo przysługujące wierzycielowi na podstawie nawiązanego stosunku zobowiązaniowego, złożone jednak z szeregu uprawnień, a w szczególności roszczeń. Warto wspomnieć, iż ostatnie z ww. pojęć jest niekiedy błędnie utożsamiane z samą wierzytelnością, choć ma ono, co do zasady, węższy zakres ${ }^{8}$. Istota roszczenia polega bowiem na możności żądania określonego zachowania się dłużnika, które jednak nie musi prowadzić do całkowitego wykonania zobowiązania (spełnienia świadczenia) ${ }^{9}$.

W związku z wyżej przedstawioną definicją wierzytelności może nasunąć się wniosek, iż sformułowanie „przeniesienie praw z umowy ubezpieczenia” jest wadliwe ${ }^{10}$. Zdaniem autora niniejszego artykułu za przedmiot umowy zawartej na podstawie art. 823 § 1 k.c. czy też 306 k.m. uznać trzeba po prostu wierzytelność przysługująca ubezpieczonemu z tytułu zawartej umowy ubezpieczenia. Przyjęcie tej tezy może budzić przy tym pewne wạtpliwości w kontekście art. 823 $\S 4$ oraz 310 k.m. Przepisy te bowiem wskazują na jeszcze inne wierzytelności, które moga przysługiwać ubezpieczonemu.

Samo określenie, czym jest wierzytelność przysługująca ubezpieczonemu tytułem umowy ubezpieczenia, nie jest z cała pewnościa zadaniem łatwym. Jak zostało wskazane powyżej, pojęcie wierzytelności jest ściśle związane z pojęciem świadczenia, które definiuje się w doktrynie prawa cywilnego jako zachowanie (lub zespół zachowań) dłużnika zgodnie z treścią zobowiązania

6. Zob. M. Safjan, [w:] Kodeks cywilny. Tom I. Komentarz. Art. 1-44910, [red.] K. Pietrzykowski, CH Beck, Warszawa 2015, s. 1069 oraz P. Machnikowski, Struktura zobowiqzania, [w:] System prawa prywatnego. Tom V. Prawo zobowiqzań - część ogólna, [red.] E. Łętowska, CH Beck, Warszawa 2013, s. 150.

7. A. Olejniczak, [w:] Kodeks cywilny. Komentarz. Tom III. Zobowiqzania-część ogólna, [red.] A. Kidyba, Wolters Kluwer, Warszawa 2014, s. 35.

8. J. Mojak, Obrót wierzytelnościami, LexisNexis, Warszawa 2012, s. 17. Stanowisko przeciwne prezentuje J. Kuropatwiński, Umowne wierzytelnościq przyszłq, TNOiK, Toruń-Bydgoszcz 2007, s. 37. W ocenie tego autora wierzytelność powinna być utożsamiana z roszczeniem obligacyjnym.

9. W. Czachórski, Zobowiqzania, Zarys wykładu, LexisNexis, Warszawa 2009, s. 51.

10. Pojęcia praw nie można utożsamiać pojęciem uprawnień, których w istocie wierzyciel może mieć wiele i które składają się na prawo podmiotowe wierzyciela w postaci wierzytelności - zob. Z. Radwański, A. Olejniczak, Prawo cywilne - część ogólna, CH Beck, Warszawa 2015, s. 87. 
i czyniące zadość interesowi wierzyciela ${ }^{11}$. Jak wskazuje się w literaturze i orzecznictwie, niejednokrotnie określone działanie lub zaniechanie dłużnika może wymagać nie jednej, lecz kilku czynności lub postaw, które łącznie dają się określić jako jedne świadczenie ${ }^{12}$. 0 ile nie budzi wątpliwości, że świadczenie ubezpieczającego polega na zapłacie składki, o tyle istota świadczenia ubezpieczyciela pozostaje sporna. Warto przy tym podkreślić, że spór o charakter świadczenia ubezpieczyciela łączony jest ze sporem o wzajemność umowy ubezpieczenia ${ }^{13}$.

Jednym z dominujących stanowisk dotyczących problematyki świadczenia ubezpieczyciela jest tzw. teoria świadczenia pieniężnego, oparta na literalnym brzmieniu art. 805 k.c. Ustawodawca wyraźnie uzależnia powstanie obowiązku świadczenia ubezpieczyciela od zajścia przewidzianego w umowie wypadku. Świadczenie ubezpieczyciela w rozumieniu art. 805 k.c. występować ma tylko wówczas, gdy w czasie trwania stosunku prawnego ubezpieczenia zajdzie wypadek ubezpieczeniowy. Wypadek ubezpieczeniowy traktowany jest więc jako przesłanka powstania obowiązku świadczenia ubezpieczyciela, która przyjmuje postać świadczenia pieniężnego ${ }^{14}$. Warto wskazać, że prezentowane stanowisko w zasadzie dominuje w orzecznictwie sądów powszechnych ${ }^{15}$.

Drugim stanowiskiem występującym w doktrynie jest teoria ryzyka. Zdaniem wielu przedstawicieli doktryny umowa ubezpieczenia jest umową wzajemna, której istota sprowadza się do tego, że ekwiwalentem składki ubezpieczeniowej jest ponoszenie przez ubezpieczyciela ryzyka zajścia wypadku ubezpieczeniowego przez cały okres obowiązywania umowy. Według zwolenników tego stanowiska potwierdzeniem tejże koncepcji jest m.in. treść art. 813 § 1 oraz 814 § 2, które wskazuja jednoznacznie, że wysokość składki powinna odpowiadać okresowi ponoszenia odpowiedzialności przez ubezpieczyciela. W uzasadnieniach tej koncepcji przywołuje się również powiązanie początku odpowiedzialności z opłaceniem składki (art. 814 § 1 k.c.), co ma mieć oparcie w zasadzie jednoczesności świadczeń charakterystycznej dla umów wzajemnych ${ }^{16}$. Wypłata odszkodowania lub świadczenia jest zgodnie z tą teoria jedynie końcowym rezultatem umowy, w której ubezpieczyciel zobowiązał się do zapewnienia ochrony ubezpieczeniowej ${ }^{17}$.

Zwolennikiem teorii ryzyka w nieco zmodyfikowanej postaci jest Marcin Orlicki. Zdaniem tego autora świadczenie ubezpieczyciela należy traktować jako specyficzną usługę, którą ustawodawca nazywa udzielaniem ochrony ubezpieczeniowej na wypadek ryzyka wystapienia zdarzeń losowych

11. W. Borysiak, [w: Kodeks cywilny. Komentarz. Zobowiqzania. Część ogólna. Tom III A, [red.] K. Osajda, CH Beck, Warszawa 2017, s. 16.

12. Tak A. Klein, Elementy zobowiqzaniowego stosunku prawnego, Wydawnictwo Uniwersytetu Wrocławskiego, Wrocław 2005, s. 49 oraz wyrok SA w Gdańsku z dnia 10 maja 2016 r., III AUa 1744/15, LEX nr 2052631.

13. B. Kucharski, op. cit., s. 36 .

14. W najnowszej literaturze teoria świadczenia pieniężnego jest aprobowana w szczególności przez Marcina Krajewskiego, zob. M. Krajewski, Umowa ubezpieczenia. Art. 805-834 k.c. Komentarz, CH Beck, Warszawa 2016, s. 36-37, a także M. Kondka, [w:] Kodeks cywilny. Komentarz. Tom II. Zobowiqzania, [red.] K. Osajda, CH Beck, Warszawa 2013, s. 1643-1644 oraz L. Ogiegło, [w:] Kodeks cywilny. Tom II. Komentarz do art. 4501088. Przepisy wprowadzajqce, [red.] K. Pietrzykowski, CH Beck, Warszawa 2013, s. 742.

15. Por. Wyrok Sądu Najwyższego z dnia 20 października 2006 r., IV CSK 125/06, LEX 357585 z glosą częściowo krytyczną B. Kucharskiego oraz Wyrok Sądu Apelacyjnego w Warszawie z dnia 10 kwietnia 2014 r., VI ACa 1114/13, LEX nr 1469451.

16. D. Fuchs, Ochrona ubezpieczeniowa jako świadczenie główne ubezpieczyciela, „Prawo Asekuracyjne” 2006, nr 2, s. 43.

17. A. Wasewicz, Umowa ubezpieczenia, [w:] Ubezpieczenia w gospodarce rynkowej, [red.] T. Sanganowski, Oficyna Wydawnicza Branta, Bydgoszcz-Poznań 2002, s. 46. 
czy też udzielaniem ochrony ubezpieczeniowej. Nie mniej jednak autor ten wskazuje, że zapłata określonej sumy pieniężnej na wypadek zajścia wypadku ubezpieczeniowego również powinna być traktowana jako świadczenie ubezpieczyciela. Zgodnie z tą koncepcja, jeżeli zajdzie określone w umowie zdarzenie losowe, to świadczenie polegające na ponoszeniu ryzyka ubezpieczeniowego zmienia się i aktualizuje w postaci obowiązku zapłaty owej sumy ${ }^{18}$. Stanowisko to należy uznać za kompromisowe wobec dwóch przedstawionych wcześniej teorii.

Zdaniem autora niniejszego opracowania zgodzić się należy poglądami tych przedstawicieli doktryny, którzy upatruja świadczenie ubezpieczyciela w ponoszeniu ryzyka zajścia wypadku ubezpieczeniowego, co ma swoje niewątpliwe uzasadnienie normatywne. Doniosłym przykładem pozostaje treść art. 813 § 1 k.c., który wskazuje jednoznacznie, iż w przypadku wygaśnięcia stosunku ubezpieczenia ubezpieczonemu przysługuje zwrot składki za niewykorzystany okres ochrony ubezpieczeniowej. Celem tego uregulowania jest niewątpliwie uniknięcie sytuacji niesłusznego „wzbogacania się” ubezpieczycieli w ten sposób, że wysokość składki przewyższałaby przejęte ryzyko wypadku ubezpieczeniowego. Warto w tym kontekście zwrócić uwagę, iż skutek w postaci proporcjonalnego zmniejszenia świadczenia jednej ze stron na skutek przedterminowego wygaśnięcia umowy sugeruje, że w okresie obowiązywania umowy druga strona wykonuje czynności stanowiące ekwiwalent tego świadczenia. Co ciekawe, w sposób zbliżony kwestia rozliczeń po wygaśnięciu umowy została uregulowana w przepisach dotyczących zlecenia. Jak wynika bowiem z art. 746 k.c., w przypadku wypowiedzenia odpłatnej umowy zlecenia przez dającego zlecenie jest on zobowiązany uiścić przyjmującemu zlecenie część wynagrodzenia odpowiadającajego dotychczasowym czynnościom. Analiza ww. przepisów nakazuje więc przyjać, iż umowa ubezpieczenia, podobnie jak odpłatna umowa zlecenia, jest umową wzajemna ${ }^{19}$, wykazująca ścisły związek pomiędzy świadczeniami obu stron, określany w literaturze jako synnalagma ${ }^{20}$.

Drugim istotnym argumentem przemawiającym za opowiedzeniem się za teorią ryzyka jest konstrukcja definicji działalności ubezpieczeniowej uregulowana w art. 4 ust. 1 ustawy o działalności ubezpieczeniowej ${ }^{21}$. Zgodnie z tym przepisem przedmiotem działalności ubezpieczycieli jest oferowanie oraz wykonywanie czynności ubezpieczeniowych związanych z oferowaniem i udzielaniem ochrony na wypadek ryzyka wystapienia skutków zdarzeń losowych. Należy zgodzić się więc z poglądem Marcina Orlickiego, iż świadczenie ubezpieczyciela stanowi specyficzną usługę przyjmujaca postać niezwykle złożonego kompleksu czynności²2.

18. M. Orlicki, Umowa ubezpieczenia, [w:] System prawa prywatnego. Tom VIII. Prawo zobowiqzań - część szczegółowa, [red.] J. Panowicz-Lipska, CH Beck, Warszawa 2011, s. 840.

19. Należy przy tym zauważyć, iż wzajemność umowy zlecenia (także odpłatnej) jest również przedmiotem kontrowersji w doktrynie. W ocenie autora niniejszego artykułu należy zgodzić się z poglądem, iż kwalifikowanie odpłatnych umów zlecenia do kategorii umów wzajemnych nie stanowi błędu - tak m.in.: L. Ogiegło, Zlecenie, [w:] System prawa prywatnego. Tom VII. Prawo zobowiqzań - część szczegółowa, [red.] J. Rajski, CH Beck, Warszawa 2011, s. 560 oraz P. Machnikowski, [w:] Kodeks cywilny. Komentarz, [red.] E. Gniewek, P. Machnikowski, CH Beck, Warszawa 2017, s. 1437. Odmiennie A. Szpunar, [w:] System prawa cywilnego. Tom III. Część II, [red.] S. Grzybowski, Zakład Narodowy im. Ossolińskich, Wrocław 1976, s. 391-392.

20. Z. Radwański, A. Olejniczak, Zobowiqzania - część ogólna, CH Beck, Warszawa 2012, s.123.

21. Ustawa z dnia z dnia 11 września 2015 r. o działalności ubezpieczeniowej i reasekuracyjnej (Dz.U.2017.1170, tj. $z$ dnia 20.06.2017).

22. M. Orlicki, Umowa ubezpieczenia..., s. 839. 
Po ustaleniu, że przedmiotem świadczenia ubezpieczyciela jest ponoszenie ryzyka zajścia wypadku ubezpieczeniowego, należy rozważyć, jaki charakter prawny ma czynność polegająca na zapłacie określonej kwoty pieniężnej już po zajściu tego wypadku. Przyjęcie klasycznej teorii ryzyka oznaczałoby konieczność stwierdzenia, że zapłata owej sumy nie stanowi odrębnego świadczenia ubezpieczyciela, lecz jedno z zachowań składających się na świadczenie w postaci ochrony ubezpieczeniowej. Istnieje również możliwość zaaprobowania koncepcji Marcina Orlickiego głoszącej, że zapłata sumy pieniężnej przez ubezpieczyciela jest zaktualizowanym świadczeniem ubezpieczyciela, które przed zajściem wypadku polegało na ponoszeniu ryzyka. Przyjęcie pierwszej z ww. teorii zmuszałoby do konkluzji, iż treścią wierzytelności ubezpieczonego jest możliwość żądania świadczenia ochrony ubezpieczeniowej. Zgodzenie się z koncepcją Marcina Orlickiego oznaczałoby natomiast, że beneficjentowi ubezpieczenia przysługiwałyby dwie odrębne wierzytelności. Przed wypadkiem ubezpieczeniowym - możliwość żądania świadczenia ochrony ubezpieczeniowej, natomiast po wypadku - możliwość żądania zapłaty określonej w umowie sumy pieniężnej.

W ocenie autora niniejszego artykułu na aprobatę zasługuje pojmowanie ochrony ubezpieczeniowej jako wyłącznego świadczenia ubezpieczyciela o jednolitym charakterze. Nie wydaje się słuszne różnicowanie świadczenia ubezpieczyciela w zależności od tego, czy określony w umowie wypadek nastapił. Obowiązek zapłaty sumy pieniężnej nie może być bowiem zrealizowany, jeżeli nie nastapiły odpowiednie działania ubezpieczyciela poprzedzające wypadek ubezpieczeniowy. Z cała pewnością wypłata sumy pieniężnej jest więc jedynie zwieńczeniem poprzedzających wypadek działań ubezpieczyciela, a jednocześnie ich ewentualną konkretyzacją ${ }^{23}$. Przedmiotowe zapatrywanie jest ponadto zgodne z opisanym wyżej rozumieniem świadczenia jako zespołu zachowań ukierunkowanych na zaspokojenie interesu wierzyciela. Należałoby wobec tego przyją́, iż przysługująca ubezpieczonemu wierzytelność polega na możliwości żądania ochrony ubezpieczeniowej (ponoszenia ryzyka zajścia wypadku przez okres obowiazywania umowy). Uprawnienie ubezpieczonego polegające na możności żądania zapłaty sumy pieniężnej po zajściu wypadku ubezpieczeniowego odpowiada z kolei pojęciu roszczenia ${ }^{24}$.

Podsumowując całość poczynionych wyżej uwag, należy uznać, iż przedmiotem umowy o której mowa w art. 823 § 1 k.c. oraz 306 k.m., jest wierzytelność polegającą na możności żądania od ubezpieczyciela świadczenia ochrony ubezpieczeniowej. Jednym z uprawnień związanych z ta wierzytelnością jest roszczenie o zapłatę sumy pieniężnej, które jednak powstaje wraz z ewentualnym nastapieniem wypadku ubezpieczeniowego. Roszczenia tego nie można z cała pewnością utożsamiać z odrębną wierzytelnością przysługującą ubezpieczonemu. Jak zostało bowiem podkreślone, zapłata sumy pieniężnej przez ubezpieczyciela nie stanowi odrębnego świadczenia ubezpieczyciela, lecz jest z jednym z zachowań mieszących się w zakresie świadczenia ochrony ubezpieczeniowej jako całości. W związku z powyższym nasuwa się wniosek, iż wbrew literalnemu brzmieniu art. 823 § 4 k.c., który stanowi o przenoszeniu wierzytelności powstałych lub mogących powstać po zajściu wypadku ubezpieczeniowego, przepis ten w istocie stanowi o przeniesieniu roszczenia (czy też roszczenia przyszłego). Ponadto, pomimo faktu, że art. 310 k.m. nie odnosi

23. B. Kucharski, op. cit., s. 50.

24. Tak również B. Kucharski, op. cit., s. 52-55 oraz J. Pokrzywniak, op. cit., s. 10 ?. 
się wprost do tych wierzytelności, które powstają po zajściu wypadku, należałoby stwierdzić, że powyższą konkluzję można odnieść również do tego przepisu²5.

Warto również podkreślić, że przyjęcie jednej z zaprezentowanych teorii dotyczących świadczenia ubezpieczyciela ma istotne znaczenie praktyczne. W przypadku przyjęcia, że ubezpieczyciel świadczy jeszcze przed zajściem wypadku ubezpieczeniowego, należałoby uznać, iż również przed tym zdarzeniem może dojść do przeniesienia wierzytelności istniejącej. Z kolei konsekwencją zaaprobowania teorii świadczenia pieniężnego byłoby dojście do wniosku przeciwnego - przed zajściem wypadku ubezpieczeniowego może dojść jedynie do przeniesienia wierzytelności przyszłej ${ }^{26}$.W celu zachowania spójności przedmiotowych rozważań dalsza analiza problematyki przeniesienia wierzytelności z ubezpieczenia majątkowego opierać się będzie na tym pierwszym stanowisku. Oznacza to w konsekwencji, iż na skutek zawarcia umowy, o której mowa w art. 823 § 1-3 k.c., może dojść co do zasady do przeniesienia wyłącznie istniejącej wierzytelności o ochronę ubezpieczeniową?

\section{Warunki oraz skutki przeniesienia praw z umowy ubezpieczenia}

Przeniesienie praw z umowy ubezpieczenia na podstawie art. 823 k.c. następuje po spełnieniu kilku przesłanek warunkujących jej skuteczność. Niespełnienie którejkolwiek z nich będzie oznaczało brak oczekiwanego skutku w postaci przeniesienia praw na nabywcę przedmiotu ubezpieczenia.

Pierwszym warunkiem wynikajacym wprost z art. $823 \S 1$ k.c. jest zbycie przedmiotu ubezpieczenia. Analizę tej przesłanki warto więc rozpocząć od ustalenia znaczenia pojęcia przedmiotu ubezpieczenia. W dalszej kolejności natomiast uzasadnione będzie wyjaśnienie zakresu znaczeniowego pojęcia zbycia.

Definicję przedmiotu ubezpieczenia zawiera treść art. 821 k.c., zgodnie z którym może być to każdy interes majątkowy, który nie jest sprzeczny z prawem i daje się ocenić w pieniądzu. Na gruncie obecnie obowiązującej regulacji ustawodawca nie wymienia więc w sposób enumeratywny, jakie dobra czy wartości moga stanowić przedmiot ubezpieczeńn ${ }^{28}$. Nie ulega jednak wạtpliwości,

25. Wyłączenie stosowania przepisów o przenoszeniu praw z umowy ubezpieczenia w art. 310 k.m. sugeruje, że podobnie jak w przepisach Kodeksu cywilnego na zasadach ogólnych mogą być przenoszone roszczenia o zapłatę odszkodowania ubezpieczeniowego.

26. W ten sposób przedmiotową problematykę ujął Sąd Najwyższy w wyroku z dnia 8 sierpnia 2003, V CK 169/02, OSP 2004, nr 10, poz. 121 z glosami M. Krajewskiego oraz B. Kucharskiego (Glosa 2005, nr 4). W orzeczeniu tym uznano, że właściwość zobowiązania wynikającego z umowy ubezpieczenia polega m.in. na tym, że będąca jego elementem wierzytelność wobec ubezpieczyciela o wypłatę odszkodowania ubezpieczeniowego jest szczególną postacią wierzytelności przyszłej, a mianowicie wierzytelnością warunkowa.

27. Odmiennie M. Krajewski, op. cit., s. 510-511. Zdaniem tego autora, który jak wspomniano jest zwolennikiem teorii świadczenia, art. $823 \S 1$ dotyczy przeniesienia wierzytelności o zapłatę określonej sumy pieniężnej, a więc tego samego, o czym mowa wart. 823 § 4. Krajewski jednak również słusznie zauważa, że obecna redakcja art. 823 k.c. jest wadliwa, oraz proponuje, aby w $\S 1$ tego przepisu mowa była o przejściu ochrony ubezpieczeniowej - zob. M. Krajewski, Przydatność i treść pojęcia ochrony ubezpieczeniowej, [w:] B. Gnela, M. Szaraniec, Kierunki rozwoju ubezpieczeń gospodarczych w Polsce. Wybrane zagadnienia prawne, DIFIN, Warszawa 2013, s. 141-144.

28. Przed nowelizacją z 2007 roku przedmiotem ubezpieczenia mogło być wyłącznie mienie bądź odpowiedzialność cywilna, co w związku z rozwojem rynku ubezpieczeń powodowało poważne problemy praktyczne. Zgodnie z literalnym brzmieniem tego przepisu nie były ubezpieczalne m.in. różne ryzyka finansowe, np. utrata zysków. 
że pojęcie interesu majątkowego odwołuje się do tak zwanej koncepcji interesu ubezpieczeniowego, tj. pewnego stosunku wartości łączącego dane dobro z konkretną osobą ${ }^{29}$. W wyjaśnieniu przedmiotowego pojęcia pomocne może być również orzecznictwo. W Wyroku Sądu Apelacyjnego w Białymstoku z dnia 22 grudnia 2016 roku stwierdzono, że „przez interes majątkowy należy rozumieć pewną wartość o charakterze ekonomicznym, którą może utracić ubezpieczony w razie zajścia wypadku przewidzianego w umowie, lub też relację pomiędzy beneficjentem ubezpieczenia a wypadkiem ubezpieczeniowym, polegającą na tym, że zajście wypadku spowoduje pewnego rodzaju uszczerbek dla beneficjenta ubezpieczenia"30. Związek pomiędzy pojęciem interesu ubezpieczeniowego a samym stosunkiem ubezpieczenia jest na tyle silny, że brak interesu po stronie ubezpieczonego w momencie zawarcia umowy powoduje nieważność umowy ubezpieczenia z uwagi na treść art. $806 \S 1$ k.c. ${ }^{31} \mathrm{~W}$ przypadku trwałego odpadnięcia interesu ubezpieczeniowego w trakcie trwania ochrony ubezpieczeniowej zastosowanie znajdą z kolei przepisy dotyczące następczej niemożliwości świadczenia, w szczególności art. 495 w zw. z art. 475 k.c. ${ }^{32}$

Zgodnie z dominująca wykładnią zbycie przedmiotu ubezpieczenia oznacza przeniesienie go na drugi podmiot w drodze syngularnej czynności prawnej. Artykuł 823 k.c. nie będzie miał więc zastosowania w przypadku sukcesji uniwersalnej, ponieważ wówczas ochrona ubezpieczeniowa przejdzie automatycznie (bez konieczności spełnienia warunków określonych w tym przepisie) ${ }^{33}$. Dodatkowo warto wskazać, iż sam interes ubezpieczeniowy nie musi wiązać się z prawem własności do rzeczy. Nie mniej w art. 823 chodzi o definitywne przejście uprawnień do przedmiotu ubezpieczenia. Dlatego nabywca przedmiotu ubezpieczenia nie jest przykładowo najemca, który jest uprawniony wyłącznie do korzystania z niego ${ }^{34}$.

Kolejnym warunkiem przedmiotowej czynności prawnej jest dokonanie zbycia przedmiotu ubezpieczenia w trakcie trwania stosunku ubezpieczeniowego łączącego dotychczasowego ubezpieczającego z ubezpieczycielem. Warunek ten jest więc spełniony, jeżeli zbycie następuje po zawarciu umowy ubezpieczenia i przed jej wygaśnięciem. Z drugiej jednak strony, nie ma znaczenia, czy ubezpieczenie było w pełni skuteczne. Wierzytelność może być przeniesiona także wtedy, gdy odpowiedzialność ubezpieczyciela nie rozpoczęła się z uwagi na nieopłacenie składki. Jak podkreśla Bartosz Kucharski, konsekwencją takiej sytuacji będzie jedynie powstanie solidarnej odpowiedzialności zbywcy oraz nabywcy przedmiotu ubezpieczenia za jej zapłatę. Uiszczenie składki pociagnie za sobą ostateczne przejście ochrony ubezpieczeniowej na nabywcę przedmiotu ubezpieczenia ${ }^{35}$.

Ostatnim warunkiem omawianej czynności jest wyrażenie zgody przez ubezpieczyciela na jej dokonanie. Warunek ten jednak nie zawsze jest konieczny, ponieważ sama umowa ubezpieczenia bądź ogólne warunki ubezpieczenia mogą przewidywać odstapienie od tego wymogu. Jak się zdaje, wprowadzenie warunku zgody ubezpieczyciela jest przede wszystkim umotywowane szczególną

29. Z. Gawlik, [w: ], Kodeks cywilny. Komentarz LEX. Zobowiqzania. Część szczegółowa, [red.] A. Kidyba, Wolters Kluwer, Warszawa 2014, s. 1062.

30. Wyrok Sądu Apelacyjnego w Białymstoku z dnia 22 grudnia 2016 r., I ACa 650/16, LEX nr 2191494.

31. M. Krajewski, Umowa ubezpieczenia..., s. 402; S. Byczko, Interes ubezpieczeniowy. Aspekty prawne, DIFIN, Warszawa 2013, s. 119.

32. Podobnie S. Byczko, op. cit., s. 122.

33. J. Pokrzywniak, op. cit., s. 105.

34. G. Sikorski, [w:] Kodeks cywilny. Komentarz, [red.] J. Ciszewski, LexisNexis, Warszawa 2014, s. 1345.

35. B. Kucharski, op. cit., s. 253. 
więzią łączącą ubezpieczonego z ubezpieczycielem. Umowa ubezpieczenia jest umową najwyższego zaufania, która przejawia się między innymi podstawowymi powinnościami ubezpieczonego w postaci deklaracji ryzyka czy też prewencji przedmiotu ubezpieczenia przed wypadkiem ubezpieczeniowym ${ }^{36}$. Osoba wierzyciela ma więc dla ubezpieczyciela kluczowe znaczenie, gdyż to właśnie z jego osobistą sytuacją może być związane ryzyko, które ubezpieczyciel zobowiązany jest przejać. Warto przy tym jednak wskazać, iż zdaniem części doktryny zgoda ubezpieczyciela nie ma w tym kontekście większego uzasadnienia, ponieważ obecne regulacje prawne chronia w sposób dostateczny interesy ubezpieczyciela w związku z nagłym wzrostem ryzyka spowodowanym zmiana po stronie ubezpieczonego podmiotu. Jak wynika bowiem z dyspozycji art. 815 § 2, $2^{1}$ i 3 k.c. oraz 816 k.c., na ubezpieczającym lub ubezpieczonym ciąży obowiązek notyfikacji zmian ryzyka, z wyłączeniem odpowiedzialności ubezpieczyciela w razie jego niedochowania oraz z możliwością zmiany wysokości składki w razie zmiany prawdopodobieństwa zajścia wypadku37.

Drugim uzasadnieniem dla warunku zgody ubezpieczyciela może wydawać się określone w art. 823 § 1 k.c. powiązanie przejścia praw (wierzytelności) z umowy ubezpieczenia z przejściem obowiązków (długu). Jak wynika z art. 519 k.c., zwalniające przejecie długu wymaga zgody wierzyciela. Warto jednak dostrzec, że omawiana zasada dotyczy wyłaccznie umownego przejścia długu, natomiast dyspozycja art. 823 § 1 stanowi o przejściu obowiązków z mocy prawa. Kodeks cywilny reguluje natomiast przypadki, w których przejście długu z mocy prawa nie wymaga zgody wierzyciela ${ }^{38}$.

Wobec braku szczegółowych uregulowań do zgody ubezpieczyciela należy stosować art. 63 k.c. Możliwe jest w związku z tym wyrażenie przedmiotowej zgody zarówno przed dokonaniem czynności przeniesienia praw, jak i po ich dokonaniu. Zgoda wyrażona po zawarciu umowy odnosi skutek z moca wsteczną od jej daty ${ }^{39}$. W przypadku przeniesienia praw przed uzyskaniem zgody ubezpieczyciela czynność ta będzie miała charakter czynności prawnej kulejącej (negotium claucidans $]^{40}$. Zgoda ubezpieczyciela dla swej skuteczności wymaga zachowania formy zastrzeżonej dla czynności, na którą zgoda jest wyrażana.

Powyższe uwagi dotyczące warunków przeniesienia praw z umowy ubezpieczenia moga zostać częściowo przeniesione na grunt ubezpieczeń morskich. Stosownie do art. 306 k.m. przeniesienie praw z umowy ubezpieczenia morskiego jest dopuszczalne wyłącznie na nabywce przedmiotu ubezpieczenia, przy czym zbycie tego przedmiotu powinno nastapić w trakcie obowiązywania umowy ubezpieczenia łączącej zbywcę z ubezpieczycielem. Należy przy tym zauważyć, że przedmiot ubezpieczenia w tym reżimie jest rozumiany jako każdy interes majątkowy związany z żegluga morską i dający się ocenić w pieniądzach ${ }^{41}$. Podstawową różnicą między przedmiotem ubezpieczenia

36. Jak wskazuje S. Byczko, Prawo ubezpieczeń gospodarczych - zarys wykładu, DIFIN, Warszawa 2013, s. 145 obowiązki prewencyjne wywodzić należy z wykładni art. 827 § 1 zd. 2 k.c., zgodnie z którym „w razie rażącego niedbalstwa odszkodowanie nie należy się, chyba że umowa lub ogólne warunki ubezpieczenia stanowią inaczej”. Uznaje się na podstawie tej regulacji, że ubezpieczyciel może nałożyć określone obowiązki, które maja zapobiec wyrządzeniu szkody.

37. Tak B. Kucharski, op. cit., s. 256.

38. Tak przykładowo art. 625 k.c. dotyczący kontraktacji oraz 678 k.c. dotyczący najmu.

39. J. Pokrzywniak, op. cit., s. 105.

40. B. Kucharski, op. cit., s. 256.

41. W art. $293 \S 2$ ustawodawca podaje następujące przykłady przedmiotu ubezpieczenia morskiego: statek, ładunek, fracht, opłata za przewóz pasażerów, opłata czarterowa, spodziewany zysk na ładunku, prowizja, 
lądowego a przedmiotem ubezpieczenia morskiego jest więc to, że interes majątkowy na gruncie ubezpieczeń morskich jest chroniony przed niebezpieczeństwami morza i na morzu ${ }^{42}$.

W unormowaniach Kodeksu morskiego inaczej przedstawia się natomiast warunek zgody ubezpieczyciela. Zgodnie z dyspozycją normy wyrażonej w art. 309 k.m. zgoda taka jest wymagana wyłącznie w przypadku, gdy przedmiotem ubezpieczenia jest statek. Jest to z cała pewnościa uzasadnione faktem, iż osoba armatora oraz charakter prowadzonej przez niego działalności może mieć duże znaczenie dla oszacowania ryzyka zajścia wypadku ubezpieczeniowego.

Po spełnieniu warunków, o których mowa powyżej, zarówno na gruncie ubezpieczeń lądowych, jak i morskich następuje wstapienie nabywcy przedmiotu ubezpieczenia w sytuację prawna zbywcy. Należy przy tym zdecydowanie podkreślić, iż o ile przejęcie praw z umowy ubezpieczenia następuje na podstawie czynności między zbywcą i nabywca przedmiotu ubezpieczenia, o tyle przejście obowiązków dokonuje się ex lege i jest skutkiem wspomnianej czynności wynikającym z ustawy ${ }^{43}$. Nabywca przedmiotu ubezpieczenia z chwilą dojścia do skutku omawianej czynności staje się, z jednej strony, podmiotem legitymowanym do realizacji wszystkich uprawnień związanych z przysługującą mu odtąd ochroną ubezpieczeniową (w tym roszczeń), a z drugiej strony - zobowiązanym do spełnienia świadczenia przysługującego ubezpieczycielowi. Bez względu na to, czy tak zwane powinności ubezpieczającego należy wiązać z jego wierzytelnością czy też długiem ${ }^{44}$, na nabywcę przechodzą bez wạtpienia również obowiązki tego rodzaju.

Wstapienie w całość obowiązków ciążących na zbywcy przedmiotu ubezpieczenia nie doznaje wyjatku. Nie mniej na gruncie art. 823 § 2 zd. 2 k.c. zbywca przedmiotu ubezpieczenia odpowiada solidarnie z nabywcą za zapłatę składki przypadającej za czas do chwili przejścia przedmiotu ubezpieczenia na nabywcę. W tym zakresie dochodzi więc do swoistego kumulatywnego przystąpienia do długu ${ }^{45}$. Przepis ten miał na celu niewątpliwie ochronę interesu ubezpieczyciela, który dzięki tej regulacji może kierować roszczenia o zapłatę tej części składki zarówno do nabywcy, jak i do zbywcy przedmiotu ubezpieczyciela. W unormowaniach Kodeksu morskiego konstrukcja tego typu nie występuje, w związku z czym zbywca przedmiotu ubezpieczenia pozostaje wolny od obowiązku zapłaty składki za okres korzystania przez niego z ochrony ubezpieczeniowej w przypadku zaniechania jej zapłaty.

Kończąc przedmiotowe rozważania, należy wspomnieć, iż jeżeli nie dojdzie do przeniesienia praw z umowy ubezpieczenia na nabywcę przedmiotu ubezpieczenia, stosunek ubezpieczenia wygaśnie z chwila przejścia przedmiotu ubezpieczenia na nabywcę ${ }^{46}$. Jest to rozwiązanie logiczne, ponieważ w związku z przejściem przedmiotu ubezpieczenia nie byłoby podmiotu, na rzecz którego mogłaby być świadczona ochrona ubezpieczeniowa. Zbywca przedmiotu ubezpiecze-

wydatki awarii wspólnej, zobowiązanie z tytułu odpowiedzialności cywilnej oraz wierzytelność zabezpieczona na statku, ładunku lub frachcie.

42. M. Adamowicz, Z. Brodecki, E. Sodolska, [w:] Kodeks morski, Komentarz, [red.] D. Pyć, I. Zużewicz-Wiewiórowska, System Informacji Prawnej LEX, 2012.

43. J. Pokrzywniak, op. cit., s. 105.

44. Niektórzy autorzy wskazuja, że powinności są obowiązkami wierzyciela, koniecznymi do należytego wykonania zobowiązania przez dłużnika (zakład ubezpieczeń), i umieszczajaje w ogólnej kategorii wymienionej w art. 354 § 2 k.c. Większość doktryny, wzorem piśmiennictwa niemieckiego, uznaje je jednak za swoistą kategorią obowiązków, charakterystyczną dla umowy ubezpieczenia - por. S. Byczko, Prawo ubezpieczeń..., s. 133.

45. B. Kucharski, op. cit., s. 255.

46. Tak art. $823 \S 3$ k.c. oraz $306 \S 2$ k.m. 
nia nie miałby już bowiem interesu ubezpieczeniowego, który - jak już zostało wskazane - jest nieodzownym elementem stosunku ubezpieczenia. Norma wyrażona wart. $823 \S 3$ ma zatem charakter ius cogens ${ }^{4 ?}$.

\section{Konstrukcja prawna przeniesienia praw z umowy ubezpieczenia}

Odrębnych uwag wymaga próba scharakteryzowania konstrukcji prawnej przeniesienia praw z umowy ubezpieczenia. Pozwoli to nie tylko lepiej zrozumieć istotę tejże czynności, ale również umożliwi udzielenie odpowiedzi na pytanie, które przepisy prawne i w jakim zakresie powinny mieć zastosowanie w sprawach nieregulowanych przez art. 823 § 1 k.c. oraz 306-310 k.m. Jak zostało już wspomniane, przeniesienie praw zgodnie z art. 823 § 1 k.c. następuje na podstawie czynności prawnej pomiędzy zbywcą a nabywca przedmiotu ubezpieczenia. Stąd też uzasadnione wydaje się w tym zakresie odwołanie do regulacji dotyczącej przelewu (cesji) wierzytelności. Sama umowa cesji jest bowiem jedynym kompleksowym uregulowaniem zmiany wierzyciela w polskim prawie cywilnym ${ }^{48}$.

Przedmiotem przelewu może być co do zasady wierzytelność istniejąca, przy czym powinna być ona w dostateczny sposób oznaczona (zindywidualizowana). Dotyczy to przede wszystkim wyraźnego określenia stosunku zobowiązaniowego, którego elementem jest zbywana wierzytelność, a zatem oznaczania stron tego stosunku, świadczenia oraz przedmiotu świadczenia ${ }^{49}$. Pewne kontrowersje budzi natomiast rozporządzanie wierzytelnościami przyszłymi, a zatem wierzytelnościami, które w chwili ich przeniesienia nie istnieją, a które maja powstać w przyszłości ${ }^{50}$. Do kategorii tej są zaliczane:

- wierzytelności warunkowe i terminowe;

- wierzytelności, które co prawda nie istnieja, ale istnieje już zobowiązaniowy stosunek prawny, w ramach którego powstaną one w przyszłości;

- wierzytelności, które nie tylko nie istnieja, ale co do których nie ma jeszcze żadnej podstawy prawnej w postaci jakiegokolwiek stosunku prawnego, a więc są one jedynie „czystą nadzieja”" powstania wierzytelności ${ }^{51}$.

Nie wdając się w szczegóły dotyczące tej niezwykle doniosłej i skomplikowanej problematyki, na potrzeby niniejszego opracowania należy przyjać za Kazimierzem Zawadą, iż przedmiotem przelewu mogą być wszystkie wymienione wyżej grupy, pod warunkiem że umowa przelewu wierzytelności przyszłej zawiera dane pozwalające ustalić w chwili zaistnienia określonej wierzytelności, iż to właśnie ona była objęta zawartą wcześniej umowa ${ }^{52}$.

47. J. Pokrzywniak, op. cit., s. 105.

48. B. Kucharski, op. cit., s. 283.

49. Wyrok Sądu Najwyższego z dnia 11 maja 1999 r., III CKN 423/98, OSNC 2000/5/92.

50. J. Mojak, op. cit., s. 20.

51. G. Kozieł, [w:] Kodeks cywilny. Komentarz. Tom III. Zobowiqzania - część ogólna, [red.] A. Kidyba, Wolters Kluwer, Warszawa 2010, s. 739.

52. K. Zawada, op. cit., s. 1031. W literaturze podnosi się, że elementami umożliwiającymi indywidualizację wierzytelności przyszłej mogą być m.in.: osoba wierzyciela, stosunek prawny, z którego wierzytelność powstanie, przedmiot świadczenia, czas, w którym wierzytelność ma powstać - zob. J. Kuropatwiński, op. cit., s. 210-213. 
Mimo iż Kodeks cywilny stanowi ogólnie o przelewie wierzytelności, nie powinno ulegać wạtpliwości, że przedmiotem przelewu mogą być tylko niektóre z roszczeń - lub innych uprawnień przysługujących wierzycielowi - albo ich części ${ }^{53}$. Uprawnienia te muszą cechować się jednak samodzielnością, która nadaje im autonomiczną wartość w obrocie ${ }^{54}$. Ponadto zbycie poszczególnego roszczenia nie powinno być sprzeczne z ustawą lub właściwością zobowiązania.

Zgodnie z art. 509 k.c. przeniesienie wierzytelności następuje na podstawie umowy łączącej zbywcę oraz nabywcę wierzytelności. Umowa ta z reguły dochodzi do skutku niezależnie od zgody, a nawet wiedzy dłużnika. Wyjątek od powyższej zasady stanowi zastrzeżenie umowne w postaci tzw. pactum de non cedendo. W sytuacji gdy wierzyciel i dłużnik postanowią, iż wierzytelność może być zbyta wyłącznie za zgodą dłużnika, skutek w postaci przejścia wierzytelności na osobę trzecią nastapi dopiero po wyrażeniu zgody dłużnika. Zastrzeżenie pactum de non cedendo ma skutek erga omnes, wobec czego umowa przelewu zawarta bez zgody dłużnika będzie jedynie czynnością prawną kulejąca ${ }^{55}$. Powyższe może budzić wạtpliwości w kontekście uregulowania art. 57 § 1 k.c. W doktrynie przyjmuje się jednak, że uregulowania art. 509 oraz 514 k.c. dotyczące tego zastrzeżenia umownego stanowią lex specialis wobec art. 57 k.c. ${ }^{56}$

Skutkiem zawarcia umowy cesji jest translatywne przeniesienie prawa podmiotowego. Kształt prawa przysługującego cedentowi pozostaje niezmieniony. Wierzytelność przechodzi na cesjonariusza w takim stanie i w takim zakresie, w jakim służyła jego poprzednikowi ${ }^{57}$. Wraz z wierzytelnościa przechodzą na nabywcę wszelkie związane z nia prawa, w szczególności roszczenie o zaległe odsetki. Przeniesienie wierzytelności wynikającej z umowy dwustronnie zobowiązującej $w$ drodze cesji nie prowadzi natomiast do równoczesnego przejścia długu ${ }^{58}$. Nie mniej jednak nie ma przeszkód, ażeby cedent oraz cesjonariusz zawarli jednocześnie dwie umowy, tj. umowę cesji oraz przejęcia długu. W takiej sytuacji następuje zmiana strony stosunku zobowiązaniowego, o ile wierzyciel (będący zarazem dłużnikiem) cedenta wyrazi zgodę na przejęcie długu.

Analiza konstrukcji przelewu oraz przeniesienia praw ze stosunku ubezpieczenia uregulowanej w art. 823 k.c. pozwala stwierdzić, iż czynności te zachowuja pewne podobieństwa. Przede wszystkim obie czynności następują poprzez zawarcie umowy pomiędzy zbywcą oraz nabywca przenoszonego prawa. Ponadto, jak zostało już wyjaśnione przedmiotem umowy uregulowanej w art. 823 k.c. §. 1-3 k.c. jest, podobnie jak w przypadku cesji, jest wierzytelność.

Przechodząc do omawiania różnić pomiędzy przedmiotowymi czynnościami, należy w pierwszej kolejności zwrócić uwagę, iż umowa przelewu dochodzi do skutku co do zasady bez zgody dłużnika, chyba że zgoda taka została przewidziana w umowie pomiędzy cedentem a dłużnikiem. W przypadku umowy przeniesienia praw z umowy ubezpieczenia warunek zgody przedstawia się odwrotnie, a więc z zasady jest on wymagany, nie mniej istnieje możliwość odstapienia od niego

53. Tak Wyrok Sądu Najwyższego z dnia 23 listopada 1999 r., II CKN 565/98, 0SNC 2000/5/98 oraz K. Zawada, op. cit., s. 1021-1022.

54. G. Kozieł, op. cit., s. 739.

55. K. Zawada, op. cit., s. 1025.

56. J. Mojak, [w:] Kodeks cywilny. Komentarz. Tom II, [red.] K. Pietrzykowski, CH Beck, Warszawa 2011, s. 192.

57. B. Kucharski, op. cit., s. 289.

58. W doktrynie pojawiło się jednak stanowisko, zgodnie z którym w niektórych umowach wzajemnych wierzytelność jest związana na tyle ściśle z długiem, że przelew wierzytelności będzie możliwy wyłącznie wtedy, gdy towarzyszyć mu będzie przejęcie długu - por. B. Kucharski, op. cit., s. 313 i powołany tam pogląd E. Łętowskiej. 
w umowie lub ogólnych warunkach ubezpieczenia. Co istotne, niezależnie od tego, czy zawierana jest umowa cesji, czy też umowa uregulowana w art. 823 k.c., brak wymaganej zgody prowadzi do bezskuteczności czynności prawnej, co stanowi wyjattek od art. 57 k.c.

Druga różnica dotyczy możliwości przenoszenia praw przyszłych. Należy z całą pewnością wykluczyć zbywanie praw z umowy ubezpieczenia przed zawarciem samej umowy ubezpieczenia, bowiem jak zostało już wyjaśnione, sama czynność zbycia przedmiotu ubezpieczenia musi nastapić w trakcie obowiązywania tej umowy. Jak się jednak wydaje, możliwe jest zbycie przedmiotu oraz praw z umowy ubezpieczenia już po zawarciu umowy ubezpieczenia, lecz przed rozpoczęciem ochrony ubezpieczeniowej. Sytuacja taka miałaby przykładowo miejsce w przypadku niezapłacenia składki bądź zastrzeżenia w umowie określonego terminu rozpoczęcia ochrony ubezpieczeniowej. Co zrozumiałe - i jak zostało już zasygnalizowane - przedmiotowa kwestia przedstawiałaby się inaczej w przypadku przyjęcia, że świadczenie ubezpieczyciela polega wyłącznie na zapłacie określonej sumy pieniężnej. W takim wypadku należałoby z kolei uznać, że na podstawie umowy, o której mowa w art. 823 § 1, dochodzi w każdym wypadku do rozporządzenia prawami przyszłymi.

Po trzecie art. 823 § 1 k.c. dotyczy przeniesienia wszystkich uprawnień związanych z ochroną ubezpieczeniową, a więc całej wierzytelności. Jak zostało zaś wskazane powyżej, instytucja umowy cesji ma zastosowanie zarówno do zbywania całej wierzytelności, jak i poszczególnych roszczeń, o ile roszczenie to cechuje się względną samodzielnością i tym samym przeniesienie pojedynczego roszczenia nie sprzeciwia się jego istocie.

Po czwarte, umowa przelewu wierzytelności, w przeciwieństwie do umowy przeniesienia praw z umowy ubezpieczenia, nie prowadzi do jednoczesnego przejścia obowiązków (długu). W celu wstapienia w całą sytuację prawną zbywcy wierzytelności konieczne jest więc zawarcie odrębnej umowy o przejęcie długu. Uwaga ta dotyczy, jak się wydaje, również umów wzajemnych wykazujących ścisły związek między świadczeniami stron.

Mając na uwadze powyższe, uzasadnione wydaje się przyjęcie tezy, iż ze względu na liczbę oraz doniosłość różnic, umowę przeniesienia praw z umowy ubezpieczenia zawartą na podstawie art. 823 § 1 należy uznać za oddzielną od przelewu instytucję prawa ubezpieczeniowego ${ }^{59}$. Powyższe potwierdza również unormowanie zawarte w art. 823 § 4 k.c., z którego można wywieść, że przepisy o przelewie mają zastosowanie do przeniesienia wierzytelności (a właściwiej rzecz ujmując - roszczenia) o odszkodowanie ubezpieczeniowe. Nie mniej nie oznacza to, iż regulacje prawne dotyczące umowy cesji nie znajdą chociażby częściowego zastosowania do umowy przeniesienia praw na podstawie art. 823 § 1 k.c. W związku z faktem, że przepisy dotyczące przelewu wierzytelności pozostają w dalszym ciągu jedynym kompleksowym uregulowaniem przejścia praw, przepisy te należałoby stosować w drodze analogii. Potrzeba stosowania przepisów o przelewie per analogiam do odrębnych od przelewu instytucji prawnych jest uznawana w doktrynie ${ }^{60}$.

Odrębnych uwag wymaga natomiast konstrukcja prawna zaproponowana przez ustawodawcę w ubezpieczeniach morskich. W tym zakresie należy wyróżnić przede wszystkim sposób przeniesienia praw z umowy ubezpieczenia. Jak wynika bowiem z art. 308 k.m., przeniesienie praw z umowy ubezpieczenia stwierdzonej polisą następuje przez przeniesienie polisy. Do samego przeniesienia polisy należy natomiast stosować w sposób odpowiedni zasady dotyczące przenoszenia konosamentu. Z przedmiotowego uregulowania wynika, iż na gruncie ubezpieczeń morskich możliwe

59. Tak również B. Kucharski, op. cit., s. 260.

60. Tak K. Zawada, op. cit., s. 1338. 
są trzy sposoby przeniesienia praw z umowy ubezpieczenia. Jeżeli ubezpieczyciel nie wystawił polisy ubezpieczeniowej bądź wystawiona została polisa imienna, przeniesienie prawa do ochrony ubezpieczeniowej następuje w drodze umowy zawartej pomiędzy zbywcą a nabywca przedmiotu ubezpieczenia ${ }^{61}$. W przypadku wystawienia polisy na zlecenie prawa z polisy przenoszone sa przez indos, natomiast prawa z polisy na okaziciela przenosi się przez proste wydanie polisy. Wymienione wyżej sposoby przenoszenia praw z polisy przypominają niewatpliwie zasady przenoszenia praw wierzytelności ucieleśnionych w papierach wartościowych ${ }^{62}$. Stąd też w doktrynie pojawiły się głosy zaliczające morskie polisy ubezpieczeniowe do kręgu papierów wartościowych ${ }^{63}$. Zdaniem autora niniejszego opracowania stanowisko to należy uznać za słuszne z tym zastrzeżeniem, że nie dotyczy ono wszystkich rodzajów morskich polis ubezpieczeniowych. Jak wynika z treści art. $336 \S 2$ k.m., ubezpieczyciel może uzależnić wypłatę odszkodowania od zwrotu polisy, chyba że polisa była imienna. Z regulacji tej wypływa więc wniosek, że w przypadku wystawienia polisy imiennej osoba uprawniona może dochodzić spełnienia świadczenia, nawet jeżeli nie będzie w stanie okazać polisy. Imienna polisa ubezpieczeniowa nie posiada więc najważniejszej cechy papieru wartościowego, polegającej na tym, że wykonywanie prawa przez uprawnionego jest uzależnione od posiadania dokumentu, i tym samym nie inkorporuje wyrażonych w niej praw ${ }^{64}$.

Należy nadto wspomnieć, iż przepis art. 307 § 2 k.m. uregulował zakres zarzutów służących ubezpieczycielowi wobec zbywcy w inny sposób niż to określono w art. 513 k.c. Co więcej, w art. 310 k.m. ustawodawca przewidział, iż podobnie jak w ubezpieczeniach lądowych, wierzytelność (w tym wierzytelność przyszła] o zapłatę odszkodowania może być przeniesiona na zasadach ogólnych bez spełnienia warunków określonych w art. 306-309 k.m. Mając więc przy tym na względzie wyżej poczynione rozważania dotyczące sposobów przenoszenia praw z ubezpieczenia morskiego, należy uznać, iż na gruncie tego reżimu prawnego przeniesienie praw stanowi względnie odrębną od cesji instytucję prawną. W tym zakresie stosowanie przepisów o przelewie wierzytelności będzie jednak uzasadnione w przypadku zaniechania wystawienia polisy ubezpieczeniowej bądź wystawienia jej na imiennie oznaczonego ubezpieczającego. W przypadku wystawienia polisy na zlecenie bądź na okaziciela, przepisy o przelewie nie znajdą zaś co do zasady zastosowania ze względu na treść art. 517 § 1 k.c.

\section{Dopuszczalność przeniesienia wierzytelności bez zbycia przedmiotu ubezpieczenia}

Analiza art. 823 § 1-3 k.c. oraz art. 306-309 k.m. może rodzić poważne wạtpliwości w zakresie dopuszczalności zbycia praw z umowy ubezpieczenia na podmiot, który nie nabył przedmiotu ubezpieczenia. Jak zostało wskazane powyżej, nieodłącznym elementem każdej umowy ubezpieczenia

61. Należy wspomnieć, że ubezpieczyciel ma obowiązek wystawienia polisy wyłącznie na żądanie ubezpieczającego (art. 294 k.m.).

62. Por. $921^{12}, 921^{9}$ oraz $921^{8}$ k.c.

63. Tak E. Kowalewski, Prawo ubezpieczeń gospodarczych, Oficyna Wydawnicza Branta, Bydgoszcz-Toruń 2002, s. 195 oraz Z. Brodecki, M. Glicz, M. Serwach, Prawo ubezpieczeń gospodarczych, Wolters Kluwer, Warszawa 2010, s. 81 ?

64. Co do cech papierów wartościowych: A. Szpunar, Charakter prawny polisy ubezpieczeniowej, „Prawo Asekuracyjne" 1999, s. 5. Podobne stanowisko co do polis imiennych wyraził B. Kucharski, op. cit., s. 156-158. 
majątkowego jest posiadanie interesu ubezpieczeniowego, tj. pewnej wartości, łączącej dane dobro z konkretną osobą. Wydaje się, że ograniczenie dopuszczalności przeniesienia wierzytelności ubezpieczeniowej wyłącznie na osoby, które nabyły dobro objęte ochroną ubezpieczeniową, stanowiłoby więc pewien wyraz aprobaty ustawodawcy wobec teorii interesu ubezpieczeniowego. Z drugiej strony, należy jednak dostrzec, iż jedna rzecz lub prawo moga generować interes ubezpieczeniowy u kilku różnych podmiotów ${ }^{65}$. Wykładnia ograniczająca dopuszczalność przeniesienia wierzytelności wyłącznie na nabywców danego dobra, prowadziłaby więc do konkluzji, iż de lege lata bezskuteczne jest przeniesienie prawa do ochrony ubezpieczeniowej na podmioty, które posiadają interes majątkowy w tym, że używają lub czerpią pożytki z prawa bądź rzeczy (np. na podstawie, najmu dzierżawy czy leasingu). W grę mogạ wchodzić również przypadki oddania rzeczy w komis bądź wydania przewoźnikowi ${ }^{66}$.

Argumentu przemawiającego za dopuszczalnościa przeniesienia praw z umowy ubezpieczenia na osobę niebędącą nabywcą przedmiotu ubezpieczenia na gruncie ubezpieczeń lądowych dostarcza porównanie dyspozycji art. 823 § 1 k.c. oraz 306 § 1 k.m. Zgodnie z drugim z ww. przepisów prawa z umowy ubezpieczenia mogą być przeniesione tylko na nabywcę przedmiotu ubezpieczenia. Obecne unormowanie zawarte w Kodeksie cywilnym nie zawiera natomiast słowa „tylko" ani innego sformułowania równoznacznego. Należy się zatem skłonić ku stanowisku, iż przynajmniej na gruncie ubezpieczeń lądowych ogół praw ubezpieczającego może być przeniesiony na rzecz podmiotu, który nie nabył samego przedmiotu ubezpieczenia, z zastrzeżeniem jednak, że posiada on inny rodzaj interesu ubezpieczeniowego w stosunku do tego dobra. Nie mniej, bardzo poważne watpliwości przyniesie konieczność rozstrzygnięcia, czy w takim wypadku należałoby stosować zasady ogólne dotyczące przenoszenia wierzytelności za pomocą umowy cesji, czy też zasady przewidziane w art. 823 § 1-3. Zdaniem autora niniejszego opracowania zasadne wydaje się drugie z ww. rozwiązań, co jest uzasadnione przyjęciem, że ustawodawca w art. 823 k.c. uregulował względnie samodzielny reżim przenoszenia wierzytelności ubezpieczeniowych.

Kolejnego problemu dostarczają regulacje zawarte w art. 823 § 4 k.c. oraz 310 k.m., które przewiduja wyjątek od zasady, iż prawa z umowy ubezpieczenia moga być przeniesione wraz z przedmiotem ubezpieczenia. Wyjątek ten dotyczy „wierzytelności, jakie powstały lub moga powstać wskutek zajścia przewidzianego w umowie wypadku", tj. prawa do odszkodowania ubezpieczeniowego. Jak zostało jednak już wyjaśnione w niniejszym artykule, samo prawo do żądania odszkodowania należy nazywać raczej roszczeniem niż wierzytelnością, stąd też może pojawić się pytanie, czy uprawnienie to ma na tyle samodzielny charakter, że może być przedmiotem obrotu w oderwaniu od całej wierzytelności ubezpieczeniowej, a także czy przeniesienie tego roszczenia nie sprzeciwia się ustawie czy też właściwości zobowiązania wynikającego ze stosunku ubezpieczenia. Najmniejsze kontrowersje w tym zakresie budzi przeniesienie roszczenia o wypłatę odszkodowania, w sytuacji gdy wypadek ubezpieczeniowy miał już miejsce. Wówczas roszczenie przedstawia już konkretną dającą się oszacować wartość majątkową, uzależniona ściśle od wysokości poniesionej szkody. W związku z powyższym przeniesienie tego rodzaju uprawnienia na dowolny podmiot nie narusza, jak się wydaje, właściwości stosunku ubezpieczeniowego, a także cechuje się wystarczającą samodzielnością. Inaczej rzecz ma się w przypadku zbywalności roszczeń przyszłych. Jak słusznie zauważa bowiem Bartosz Kucharski, przeniesienie

65. B. Kucharski, op. cit., s. 353.

66. Ibidem, s. 319. 
roszczenia o zapłatę odszkodowania przed zajściem wypadku spowodowałoby, że wierzytelność ubezpieczającego polegająca na przysługującej mu ochronie ubezpieczeniowej byłaby pozbawiona znaczenia, gdyż roszczenie o wypłatę odszkodowania stanowi konkretyzację oraz zwieńczenie działań ubezpieczyciela. Ponadto warto podkreślić, iż nawet przy przyjęciu samodzielności tego przyszłego roszczenia o zapłatę odszkodowania, dopuszczalność zbycia tego prawa na osobę nieposiadająca jakiegokolwiek interesu ubezpieczeniowego mogłaby powodować zainteresowanie nabywcy tego roszczenia w zajściu wypadku ubezpieczeniowego, co jest niewatpliwie sprzeczne z samą istotą umowy ubezpieczenia. Zdaniem autora niniejszego opracowania należy więc skłonić się ku stanowisku, iż wbrew literalnemu brzmieniu art. 823 § 4 k.c. oraz 310 k.m. uprawnienie do żądania zapłaty odszkodowania jeszcze przed zajściem wypadku ubezpieczeniowego może zostać przeniesione łącznie z pozostałymi uprawnieniami ubezpieczającego na podmiot posiadający określony interes ubezpieczeniowy.

\section{Podsumowanie}

Problematyka przenoszenia wierzytelności z umowy ubezpieczenia majątkowego została uregulowana w sposób niejasny. W przepisach art. 823 § 1 oraz 306 k.m. jest bowiem mowa o „prawach z umowy ubezpieczenia”, natomiast w art. 823 § 4 oraz 310 k.m. o „wierzytelnościach”, co może sugerować, że przedmiotem obrotu moga być jeszcze jakieś inne prawa niebędące wierzytelnościami. W celu uniknięcia zbędnych wạtpliwości de lege ferenda należałoby więc doprecyzować, iż czynność określona w art. 823 § 1 k.c. oraz 306 k.m. dotyczy całej wierzytelności ubezpieczeniowej, natomiast w art. 306 § 4 k.c. i 310 k.m. - roszczenia o zapłatę odszkodowania.

Dodatkowo trzeba wskazać, iż nie do końca jasny pozostaje charakter prawny czynności przeniesienia praw z umowy ubezpieczenia. Pomimo niewątpliwego faktu, że jej przedmiotem jest wierzytelność, na podstawie licznych wyjątków od reguł ustanowionych w art. 509-518 k.c. słuszne wydaje się stwierdzenie, iż ustawodawca postanowił uregulować w sposób kompleksowy odrębną od przelewu instytucję prawną. Powyższe może rodzić problemy dotyczące zastosowania poszczególnych przepisów o przelewie choćby per analogiam.

Omawiane przepisy rodzą również poważne problemy jeśli chodzi o określenie dopuszczalności przeniesienia wierzytelności ubezpieczeniowej na podmiot niebędący nabywca przedmiotu ubezpieczenia. Powyższe wynika z faktu, iż ustawodawca niejako powiązał czynność prawna przeniesienia praw z samym zbyciem przedmiotu ubezpieczenia. Nie mniej, zasadne wydaje się stanowisko, iż dokonanie przeniesienia wierzytelności ubezpieczeniowej w drodze przelewu jest jak najbardziej możliwe, o ile cesjonariusz posiada wobec ubezpieczonego dobra określony interes majątkowy. Za dopuszczalne należy uznać również przeniesienie roszczenia o zapłatę odszkodowania już po zajściu wypadku ubezpieczeniowego, w tym na osobę, która nie posiada interesu ubezpieczeniowego. Ze względu na naturę stosunku ubezpieczenia poważne wątpliwości może budzić natomiast dopuszczalność przenoszenia roszczeń przyszłych.

Omówione wạtpliwości związane z konstrukcja prawną czynności przenoszącej prawa z umowy ubezpieczenia czy też samą dopuszczalnością zbywania tych praw na podmiot, który nie nabył przedmiotu ubezpieczenia, nie pozostają bez znaczenia dla praktyki obrotu. Przeniesienie praw z umowy ubezpieczenia jest wykorzystywane między innymi przez banki, które w ten sposób 
zabezpieczają się przed potencjalnymi negatywnymi konsekwencjami utraty bądź zniszczenia rzeczy stanowiącej przedmiot zabezpieczenia kredytu czy pożyczki. Przyjęcie, że tego typu umowy w praktyce dotyczą wierzytelności ubezpieczeniowej, może prima facie skłaniać do wniosku, iż skuteczność tejże czynności jest uzależniona od przejścia przedmiotu ubezpieczenia oraz wyrażenia stosownej zgody przez ubezpieczyciela, a także powoduje jednoczesne przejęcie długu. Nie można w tym zakresie wykluczyć jednak innych potencjalnych stanowisk dotyczących charakteru prawnego tego rodzaju czynności, w tym zapatrywania, iż przeniesienie wierzytelności z umowy ubezpieczenia na bank jest w takim wypadku skuteczne bez konieczności spełnienia przesłanek z art. 823 § 1-3 k.c., ponieważ przepisy te nie wyłączają dopuszczalności przeniesienia wierzytelności na podmiot, który nie nabył przedmiotu ubezpieczenia. Możliwe jest również przyjęcie, iż przedmiotem takiej umowy jest wyłącznie prawo do odszkodowania ubezpieczeniowego, które może być - zgodnie z literalnym brzmieniem art. 823 § 4 k.c. - przeniesione na zasadach ogólnych. Mnogość potencjalnych interpretacji w tym zakresie z cała pewnością nie sprzyja pożądanej przez uczestników obrotu pewności prawnej.

Zarysowane wyżej problemy przemawiaja za odstapieniem od obecnej regulacji, która wiąże skutki zbycia przedmiotu ubezpieczenia z samą czynnością przeniesienia wierzytelności ubezpieczeniowej, na rzecz zasad ogólnych. Jedynym uzasadnionym obostrzeniem dotyczącym przelewu wierzytelności z umowy ubezpieczenia powinna być dopuszczalność dokonania przeniesienia tego prawa na rzecz osoby, która posiada określony interes ubezpieczeniowy. Warunek ten nie wymaga jednak szczegółowej regulacji, ponieważ zawierałby się on w normie przewidującej nieważność cesji sprzecznej z właściwością zobowiązania (art. 510 w zw. z art. 58 k.c.). Należy w związku z tym zgodzić się ze stanowiskiem, iż regulacja dotycząca przelewu stanowi kompleksowy reżim przeniesienia wierzytelności i pozwala w sposób satysfakcjonujący rozwiązać większość zagadnień pojawiających się przy okazji przenoszenia praw z umowy ubezpieczenia ${ }^{6 ?}$.

Uzupełniając poczynione rozważania dotyczące przenoszenia praw z umowy ubezpieczenia majątkowego, warto zasygnalizować, iż spore znaczenie praktyczne ma nie tylko sytuacja, gdy to beneficjent ubezpieczenia zbywa swoją wierzytelność na rzecz podmiotu trzeciego, ale również gdy czyni to sam ubezpieczyciel. W tym zakresie pewnych wạtpliwości może dostarczać treść art. $385^{3}$ pkt 5 k.c., zgodnie z którym w razie wạtpliwości uważa się, że postanowienie zezwalajace kontrahentowi konsumenta na przeniesienie praw i przekazanie obowiązków wynikających z umowy bez zgody konsumenta stanowi niedozwolone postanowienie umowne (klauzulę abuzywna]. Jak się przyjmuje w doktrynie i orzecznictwie, przepis ten nie wprowadza jednak wyjatku od reguł ustanowionych w przepisach Kodeksu cywilnego regulujących instytucje przelewu oraz przejęcia długu, a w szczególności nie stanowi o tym, że przedsiębiorca w ogóle nie może przenieść przysługującej mu wierzytelności bez zgody konsumenta, lecz stanowi wyraz dezaprobaty dla postanowień „wzorcowych” lub „umownych”, w których konsument z góry wyraża zgodę na dokonanie przez przedsiębiorcę czynności prawnych skutkujących zmianą podmiotu po jednej ze stron stosunku prawnego ${ }^{68}$.

67. Ibidem, s. 355 .

68. Zob. M. Bednarek, Wzorce umów, [w:] System prawa prywatnego. Prawo zobowiqzań - część ogólna. Tom V, [red.] E. Łętowska, CH Beck, Warszawa 2013, s. 789-790; S. Pasieka, Prawne aspekty przelewu wierzytelności konsumenckiej, [w:] B. Gnela, Ochrona konsumentów usług finansowych. Wybrane zagadnienia prawne, Wolters Kluwer, Warszawa 2007, s. 758-760; W. Popiołek, [w: Kodeks cywilny. Tom I. Komentarz. 


\section{Wykaz źródeł}

Adamowicz M., Brodecki Z., Sodolska E., [w:] Kodeks morski. Komentarz, Pyć D., ZużewiczWiewiórowska I. [red.], System Informacji Prawnej LEX, 2012.

Bednarek M., Wzorce umów, [w:] System prawa prywatnego. Prawo zobowiqzań - część ogólna. Tom V, Łętowska E. [red.], CH Beck, Warszawa 2013.

Borysiak W., [w:] Kodeks cywilny. Komentarz. Zobowiqzania. Część ogólna, Tom III A., Osajda K. [red.], CH Beck, Warszawa 2017

Brodecki Z., Glicz M., Serwach M., Prawo ubezpieczeń gospodarczych. Tom I. Komentarz, Wolters Kluwer, Warszawa 2010.

Byczko S., Prawo ubezpieczeń gospodarczych - zarys wykładu, DIFIN, Warszawa 2013.

Byczko S., Interes ubezpieczeniowy. Aspekty prawne, DIFIN, Warszawa 2013.

Czachórski W., Zobowiqzania, Zarys wykładu, LexisNexis, Warszawa 2009.

Fuchs D., Ochrona ubezpieczeniowa jako świadczenie główne ubezpieczyciela, „Prawo Asekuracyjne” 2006, nr 2 .

Gawlik Z., [w:] Kodeks cywilny. Komentarz LEX. Zobowiqzania. Część szczegółowa, Kidyba A. [red.], Wolters Kluwer, Warszawa 2014.

Klein A., Elementy zobowiqzaniowego stosunku prawnego, Wydawnictwo Uniwersytetu Wrocławskiego, Wrocław 2005.

Kondek M., [w:] Kodeks cywilny. Komentarz. Tom II. Zobowiqzania, Osajda K. [red.], CH Beck, Warszawa 2013.

Kowalewski E., Prawo ubezpieczeń gospodarczych, Oficyna Wydawnicza Branta, BydgoszczToruń 2002.

Kozieł G., [w: ] Kodeks cywilny. Komentarz. Tom III. Zobowiqzania - część ogólna, Kidyba A. [red.], Wolters Kluwer, Warszawa 2010.

Krajewski M., Umowa ubezpieczenia. Art. 805-834 k.c. Komentarz, CH Beck, Warszawa 2016.

Krajewski M., Przydatność i treść pojęcia ochrony ubezpieczeniowej, [w:] Gnela B., Szaraniec M., Kierunki rozwoju ubezpieczeń gospodarczych w Polsce. Wybrane zagadnienia prawne, DIFIN, Warszawa 2013.

Kucharski B., Przeniesienie praw z umowy ubezpieczenia, Wolters Kluwer, Warszawa 2010.

Kuropatwiński J., Umowne wierzytelnościq przyszła, TNOiK, Toruń-Bydgoszcz 2007.

Machnikowski P., Struktura zobowiqzania, [w:] System prawa prywatnego. Tom V. Prawo zobowiqzań - część ogólna, Łętowska E. [red.], CH Beck, Warszawa 2013.

Machnikowski P., [w:] Kodeks cywilny. Komentarz, Gniewek E., Machnikowski P. [red.], CH Beck, Warszawa 2017.

Mojak J., Obrót wierzytelnościami, LexisNexis, Warszawa 2012.

Mojak J., [w:] Kodeks cywilny. Komentarz. Tom II, Pietrzykowski K. [red.], CH Beck, Warszawa 2011. Ogiegło L., Zlecenie, [w:] System prawa prywatnego. Tom VII. Prawo zobowiqzań - część szczegółowa, Rajski J. [red.], CH Beck, Warszawa 2011. 
Ogiegło L., [w]: Kodeks cywilny. Tom II. Komentarz do art. 450-1088. Przepisy wprowadzajace, Pietrzykowski K. [red.], CH Beck, Warszawa 2013.

Olejniczak A, [w:] Kodeks cywilny. Komentarz. Tom III. Zobowiqzania - część ogólna, Kidyba A. [red.], Wolters Kluwer, Warszawa 2014.

Orlicki M., Umowa ubezpieczenia, [w:] System prawa prywatnego. Tom VIII. Prawo zobowiqzań część szczegółowa, Panowicz-Lipska J. [red.], CH Beck, Warszawa 2011.

Pasieka S., Prawne aspekty przelewu wierzytelności konsumenckiej, [w:] Gnela B., Ochrona konsumentów usług finansowych. Wybrane zagadnienia prawne, Wolters Kluwer, Warszawa 2007. Pokrzywniak J., Komentarz do niektórych przepisów Kodeksu cywilnego, [w:] Orlicki M., Pokrzywniak J., Umowa ubezpieczenia. Komentarz do nowelizacji Kodeksu cywilnego, Wolters Kluwer, Warszawa 2008.

Popiołek W., [w:] Kodeks cywilny. Tom I. Komentarz. Art. 1-44910, Pietrzykowski K. [red.], CH Beck, Warszawa 2015.

Radwański Z., Olejniczak A., Prawo cywilne - część ogólna, CH Beck, Warszawa 2015.

Radwański Z., Olejniczak A., Zobowiqzania - część ogólna, CH Beck, Warszawa 2012.

Safjan M., [w:] Kodeks cywilny. Tom I. Komentarz. Art. 1-449 ${ }^{10}$, Pietrzykowski K. [red.], CH Beck, Warszawa 2015.

Sikorski G., [w:] Kodeks cywilny. Komentarz, Ciszewski J. [red.], LexisNexis, Warszawa 2014.

Szpunar A., Charakter prawny polisy ubezpieczeniowej, „Prawo Asekuracyjne” 1999, nr 2.

Szpunar A., [w:] System prawa cywilnego. Tom III. Część II, Grzybowski S. [red.], Zakład Narodowy im. Ossolińskich, Wrocław 1976.

Wassewicz A., Umowa ubezpieczenia, [w:] Ubezpieczenia w gospodarce rynkowej, Sanganowski T.

[red.], Oficyna Wydawnicza Branta, Bydgoszcz-Poznań 2002.

Zawada K., Przelew wierzytelności, [w]: System prawa prywatnego. Tom VI. Prawo zobowiqzań część ogólna, Olejniczak A. [red.], CH Beck, Warszawa 2009.

\section{Transfer of rights arising from the contract of property insurance}

The aim of the article is to analyze the issue of the transfer of rights arising from the contract of property insurance. In this respect, the author gives specific attention to the content of art. 823 of the Civil code and art. 306-310 of the Maritime code which concern the problem of transfer of rights in the case of alienation of the insurance's object, and the clarification of the relationship of these provisions to the general rules governing the assignment. The considerations outlined in the article concentrates also at answering the question whether and to what extent the rights arising from the contract of insurance may be transferred to the person who has not acquired the insurance's object or to the person who does not have any other insurable interest related to the property covered by insurance.

Keywords: transfer of rights arising from the contract of insurance, assignment, alienation of the insurance's object, insurable interest, insurance coverage, property insurance.

MGR ARTUR GRUSZCZYŃSKI - absolwent Wydziału Prawa i Administracji Uniwersytetu Gdańskiego, e-mail: arturgruszczynski1@wp.pl 
